\title{
Vasculogenesis in the early quail blastodisc as studied with a monoclonal antibody recognizing endothelial cells
}

\author{
LUC PARDANAUD ${ }^{1}$, CURTIS ALTMANN $^{2}$, PAUL KITOS $^{3}$, FRANCOISE DIETERLEN-LIEVRE $^{1}$ \\ and CLAYTON A. BUCK ${ }^{2}$ \\ ${ }^{1}$ Institut d'Embryologie du College de France, et du CNRS, 94736 Nogent-sur-Marne, Cedex, France \\ ${ }^{2}$ Wistar Institute, 36th Street at Spruce, Philadelphia, PA 19104, USA \\ ${ }^{3}$ Department of Blochemistry, Kansas University, Lawrence, KS, USA
}

\section{Summary}

QH1, a monoclonal antibody that recognizes quail endothelial and haemopoietic cells, was applied to quail blastodiscs in toto, in order to analyse by immunofluorescence the emergence of the vascular tree. The first endothelial cells were detected in the area opaca at the headfold stage and in the area pellucida at the 1-somite stage. Single cells then interconnected progressively, especially in the anterior intestinal portal and along the somites building up the linings of the heart and dorsal aortas. This study demonstrates that endothelial cells differentiate as single entities $4 \mathrm{~h}$ earlier in development than hitherto detected and that the vascular network forms secondarily. The horseshoe shape of the extraembryonic area vasculosa is also a secondary acquisition. A nonvascularized area persists until later (at least the 14-somite stage) in the region of the regressing primitive streak.

Key words: vasculogenesis, quail, blastodisc, monoclonal antibody, endothelial cell, QH1.

\section{Introduction}

The formation of the embryonic vasculature can be considered in two separate stages. The first commences in the extraembryonic membranes shortly after the establishment of the mesoderm. It is evidenced by the formation of clusters of cells which have been designated haemangioblasts and which eventually give rise to the embryonic blood islands (see review by Wagner, 1980). This process continues with the subsequent appearance of vessels in the area pellucida and in the embryo itself.

The second stage of vascular development occurs during organogenesis after the formation of the primitive embryonic vasculature is well underway. It is distinguished from the first in that it is initiated not by the differentiation of cells from the mesoderm, but by the budding of preformed endothelial cells from the established primary embryonic vasculature (reviewed in Wagner, 1980; Sariola, 1985). Our knowledge of this second stage, budding angiogenesis, has progressed rapidly due to the fact that the cells can be readily identified and that several experimental systems have been developed which have allowed a detailed comparison of this process with tumour angiogenesis and wound healing (Wagner, 1980; Schor \& Schor, 1983; Sariola, 1985; Folkman, 1985). In contrast, our knowledge of the formation of the primary embryonic vasculature has progressed little since the studies of Sabin (1920). Earlier work by Reagan (1915) established that the embryonic vasculature arose in situ from the area pellucida rather than by invasion of cells from the area opaca. Sabin (1920) described the formation of plexi by the coming together of small vessels, the fusion of vessels into what she interpreted as syncitia, the formation of the vascular lumen by what she perceived to be liquefaction of cells, the gradual enlargement of vessels along the major vascular routes, and finally, the anastomosing of vessels in the area pellucida and area opaca. Her observations have been refined by more recent ultrastructural studies of vasculogenesis in the area opaca (Gonzalez-Crussi, 1971; Murphy \& Carlson, 1978) and the area pellucida (Hirakow \& Hiruma, 1981, 1983). These investigations essentially 
confirmed many of the observations of Sabin with some important exceptions. They found that what she perceived as syncitia were, in fact, plexi of individual cells and that her concept of lumen formation by liquefaction of cells within syncitia was incorrect. As pointed out by Gonzalez-Crussi (1971) and Hirakow \& Hiruma $(1981,1983)$ investigations into earlier events in the establishment of the embryonic vasculature require methods that allow the identification of presumptive endothelial cells prior to their incorporation into microvessels. To this end, we began the production of monoclonal antibodies which could be used to detect vascular endothelial cells in the early embryo. We report here the use of one such antibody, designated $\mathrm{QH} 1$, to follow vascular development in the quail blastodisc with particular emphasis on processes occurring within the area pellucida. A preliminary description of this work has been previously reported (Buck, Dieterlen, Pardanaud, Kitos \& Altmann, 1985).

\section{Materlals and methods}

\section{Preparation of the blastodiscs}

Eggs of the quail (Coturnix coturnix japonica) were incubated for 24 to $30 \mathrm{~h}$. Due to the developmental variations between embryos, this timing provided all stages between primitive streak and seven to eight pairs of somites. Eggs were opened through the pointed end. Albumen was trimmed away as thoroughly as possible from the yolk, which was then poured into phosphate-buffered saline (PBS). The blastodisc was then isolated by means of a circular incision, carefully cleaned of yolk platelets and separated from the vitelline membrane. It is particularly important to eliminate yolk granules in order to achieve translucence of the preparations. The blastodisc was next positioned flat, ventral side down, in a Petri dish. Folds were avoided carefully.

\section{Fixation and immunostaining}

Fixation was performed in $4 \%$ paraformaldehyde in $\mathrm{pH} 7.4$ PBS at $4^{\circ} \mathrm{C}$ during 2 to $3 \mathrm{~h}$. The blastodiscs were then rinsed twice in PBS at room temperature and further treated for $1 \mathrm{~h}$ in two or three washes of $10 \%$ methanol at $-20^{\circ} \mathrm{C}$ for $1 \mathrm{~h}$. This step ensured their permeabilization to antibody penetration.

The blastodiscs were rehydrated through a graded series of $15-20 \mathrm{~min}$ baths of ethanol $100 \%, 95 \%$ and $70 \%$ at $4{ }^{\circ} \mathrm{C}$ followed by one $50 \%$ bath at room temperature and three PBS washes. They were then immersed in $200 \mu \mathrm{l}$ of preimmune rabbit serum diluted 20 -fold and allowed to stand overnight at $4^{\circ} \mathrm{C}$. The next morning the preparations were placed at room temperature for $45 \mathrm{~min}$ before pipetting out the serum. After three PBS rinses ( $30 \mathrm{~min}$ each) the blastodiscs were immersed into $200 \mu$ l of the QH1-containing ascites fluid diluted 100 -fold and let stand at $4^{\circ} \mathrm{C}$ overnight. After $45 \mathrm{~min}$ at room temperature, the antibody was removed and the three PBS washes were repeated.
$200 \mu$ of goat anti-mouse IgG (Nordic) coupled to fluorescein isothiocyanate diluted 50 -fold were applied overnight at $4{ }^{\circ} \mathrm{C}$. Again, after $45 \mathrm{~min}$ at room temperature, three PBS rinses were performed.

Finally, the blastodiscs were dehydrated at room temperature through successive $20 \mathrm{~min}$ baths in the following order: ethanol $50 \%, 70 \%, 95 \%, 100 \%$ twice, toluene twice. The preparations were mounted ventral side upwards in Eukitt (Prolabo) and observed with either a Leitz Dialux or a Zeiss photomicroscope III equipped with u.v. epifluorescence.

Embryos prepared for immunostaining of sections were fixed in Bouin's fluid, dehydrated and embedded in paraffin. They were treated through the same succession of baths as blastodiscs, except that the methanol baths were omitted and that each antibody exposure was for $30 \mathrm{~min}$.

\section{Grafting experiments}

In order to demonstrate the species specificity of the monoclonal antibody, combinations of quail and chick tissues were performed in vivo. The grafted rudiment was the aorta from 4-day quail embryos. This vessel has been shown previously to give rise to an abundant progeny of haemopoietic cells when grafted into a proper environment, i.e. the dorsal mesentery of the 3-day chick embryo. Besides haemopoietic cells, endothelial cells are also found to be grafted, which may be the ones originally present in the vessel and/or newly formed ones. The aorta was grafted into the coelom of a 3-day chick embryo. Cells from the graft penetrate and blend into the dorsal mesentery of the host (Dieterlen-Lievre, 1984a).

\section{Monoclonal antibodies}

Bone marrow cells were flushed from the tibias of 12-day quail embryos. Balb/C mice were injected three times at 10-day intervals with $5 \times 10^{6}$ cells suspended in PBS. 5 days after the third injection, the spleens were harvested and single cells fused with $\mathrm{Sp} 2 / 0$ myeloma cells as described in Peault, Thiery \& Le Douarin (1983). Hybridomas were screened by immunofluorescence using 12-day quail bone marrow cells $\left(10^{3}\right.$ cells per well) incubated overnight in Terasaki plates (Nunc) and fixed with $4 \%$ paraformaldehyde. 14 strongly positive hybridomas were selected and cloned. Following three reclonings, 10 hybridomas were selected for further study. All appeared to have the same tissue specificities. QH1 was selected for use in these studies because of its strong reactivity with paraffin sections of quail embryos (Dieterlen-Lievre, 1984b).

\section{Results}

\section{(A) Tissue and species specificity of the monoclonal} antibody $Q H 1$.

Fig. 1 shows a cross section of a 4-day quail embryo treated with the monoclonal antibody $\mathrm{QH} 1$ and subsequently with fluorescein-labelled goat antimouse IgG. The antibody can be seen to react essentially with two cell types, the endothelial cells lining the dorsal aorta, common cardinal vein and 


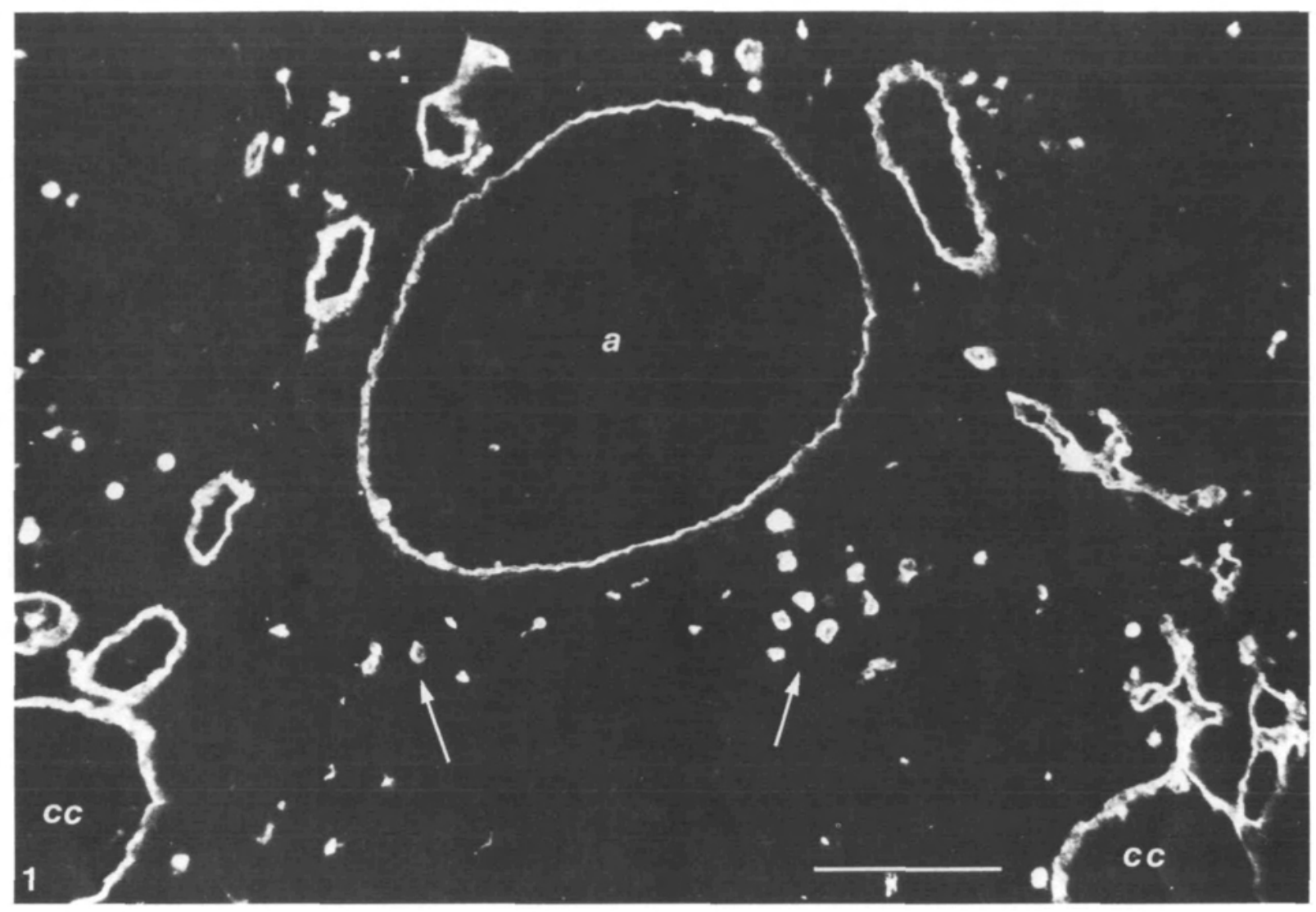

Fig. 1. Cross section of a 4-day quail embryo at the thoracic level exposed to QH1 antibody. All endothelial cells as well as small groups of haemopoietic precursors (unconnected cells indicated by arrows) are clearly fluorescent. $a$, aorta; $c c$, common cardinal veins. Bar, $100 \mu \mathrm{m}$.

minor blood vessels, and single cells in the mesenchyme shown previously to be haemopoietic precursors (Dieterlen-Lievre \& Martin, 1981). The fluorescence shown here is typical in that the primary targets of the QH1 antibody are endothelial cells and haemopoietic stem cells. Mature red blood cells do not bind this antibody. Control sections exposed to the second fluorescein-conjugated goat antimouse serum showed only background fluorescence. Sections stained with other irrelevant, monoclonal antibodies also showed only weak background fluorescence. Hence, none of the specific reactions seen with $\mathrm{QH} 1$ is due to nonspecific binding of the antibody to cells.

To demonstrate further the specificity of QH1 and its potential usefulness to trace the quail haemangioblastic lineage in chimaeric embryos, a segment of the dorsal aorta from a 4-day quail embryo was grafted into the coelom of a 3-day chick embryo. Two days after grafting, the embryo was harvested, sectioned and treated with QH1. Quail cells that have migrated out of the grafted vessel have settled into the endothelium of a vessel of the host (Fig. 2). Only they react with the antibody. It is clear that the antibody has affinity for the entire periphery of quail endothelial cells and that QH1 monoclonal antibody reacts only with endothelium contributed by the quail. That this staining pattern is not an unusual feature of this monoclonal antibody is shown by the fact that we have isolated a total of 14 independent hybridomas all producing antibodies with similar specificities (data not shown).

\section{(B) Organization of QH1-positive cells into} presumptive blood islands

QH1 monoclonal antibody appeared in cross section to react with both haemopoietic stem cells and vascular endothelium. These cell types can be easily distinguished from one another on the basis of time of appearance and location within the embryo. Therefore, it was clear that this antibody might be useful in studying the establishment of the vascular tree beginning at the time when single endothelial cells first arise and continuing through the time when they are organized into the primary vasculature of the developing embryo. To do this, wholemounts of quail embryos from the primitive streak stage through the 7-somite stage were reacted with QH1 followed by fluorescein-labelled anti-mouse IgG. 


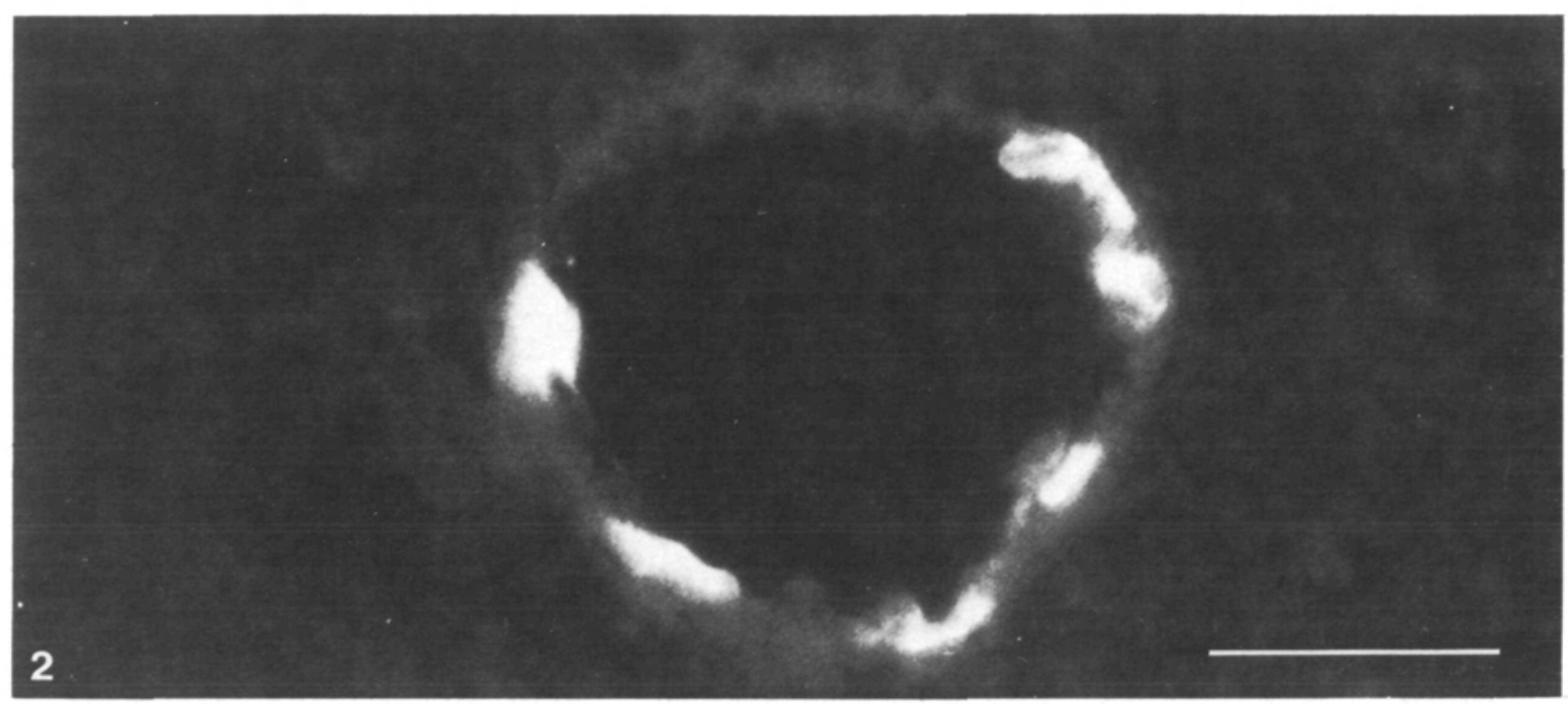

Fig. 2. Demonstration of quail/chick chimaerism in endothelium by immunofluorescence using QH1 monoclonal antibody. Following the coelomic graft of a quail aorta into a chick embryo, single fluorescent quail cells can be seen inserted among nonfluorescent chick cells of a host vessel. Note that the entire surface of quail cells is fluorescent. Bar, $25 \mu \mathrm{m}$.

In order to view the details of early events in blood island and embryonic vascular formation, the wholemounts were examined at the higher magnifications required to detect single cells at early stages in development. In Fig. 3, blood island formation and vascular network formation are compared at the cellular level. Blood island formation is first detected at the head-process stage. Isolated QH1-positive cells sometimes with cytoplasmic protrusions as seen in Fig. 4B are the first signs of blood island formation. More advanced stages of blood island formation are evidenced by clusters of four to eight cells joined by a small bridge (Fig. 3A) or single clusters with protrusions as shown in Fig. 3B. As a blood island matures, the cells appear to be organized such that some form the outer endothelium and others remain in the interior presumably to begin haemopoiesis (Fig. 3C). However, whether this is a point at which QH1-positive precursor cells become committed to either endothelium formation or haemopoiesis is not known.

The formation of the embryonic vascular network begins in the area pellucida slightly later, around the headfold stage. Again, single cells, some with thin thread-like cytoplasmic protrusions, are seen arising from the mesoderm. They appear to join via these protrusions as seen in Fig. 3D. As development progresses, more and more of these cells can be seen to emerge and connect with others forming a filamentous network (Fig. 3E). Numerous examples of this process are readily detected in the 1- to 2 -somite embryo so that by the 3- to 5-somite stage thin threadlike networks of interconnecting cells are readily visible. In older embryos, these networks thicken in the regions of major vessel formation. Whether this thickening is due to the recruitment of more cells into the network, or the division of cells already there or both, cannot be determined by these observations.

\section{(C) Distribution of monoclonal-antibody-positive cells in the developing blastodisc}

In order to obtain an overview of vascularization and a sense of the dynamics of the process, montages were prepared from a series of micrographs of whole blastodiscs. Representative wholemounts are shown in Figs 4-7. The architecture of the embryo is visible because of a general background of fluorescence. This background is not due to the monoclonal antibody as it is seen in completely unstained specimens and hence appears to be endogenous to the embryonic tissues themselves. The antibody-positive cells are however readily visible above this background as a result of their much brighter fluorescence.

In wholemounts of single-somite-stage embryos, numerous isolated single cells that react with $\mathrm{QH} 1$ are found at the boundary of the area opaca and the area pellucida in the anterior half of the blastodisc (Fig. 4A). This crescent distribution is typical of primordial germ cells (Swift, 1914). In the earliest stages studied, including the unincubated blastodisc, these cells were present. As development proceeds, these cells remain single and are never incorporated as part of the vascular endothelium (Fig. 4C). The fact that these cells, besides remaining isolated, are found in later embryos as clusters in the region of the proamnion (Fig. 7 insert) where no mesoderm is 
present, has led us to tentatively identify them as germ cells. The size, shape and location of these cells at different times of development are consistent with this interpretation. Identification of these cells by means of other markers has been performed and will be reported with a more detailed study of their distribution.

In Fig. 4A, vascular endothelial cells are also visible but only in the area opaca cephalic to the level of the first somite (Fig. 4A, framed area). They can be distinguished from germ cells by the fact that they are interconnected, less perfectly spherical and frequently show short cytoplasmic protrusions (Fig. 4B). As the embryo develops, the appearance of QH1-positive cells continues rapidly in the area opaca progressing in both rostral and caudal directions.

In the area pellucida, QH1-positive cells are initially seen intermittently at the first to second somite stage depending upon the embryo examined. It is noted that the cells are sparse and they are not organized in any particular manner except that they tend to be seen between the headfold and somite level. Endothelial cell organization proceeds rapidly
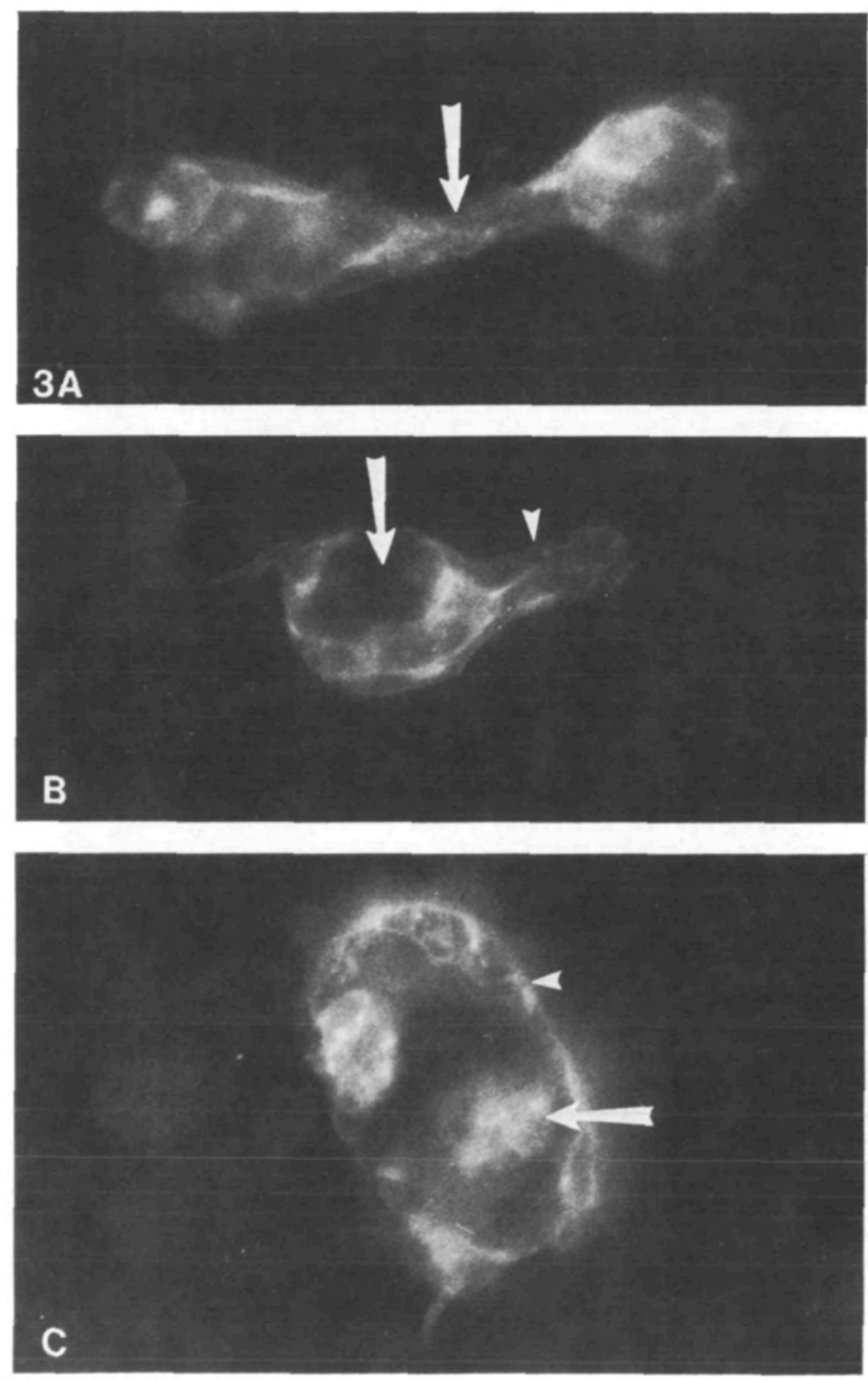
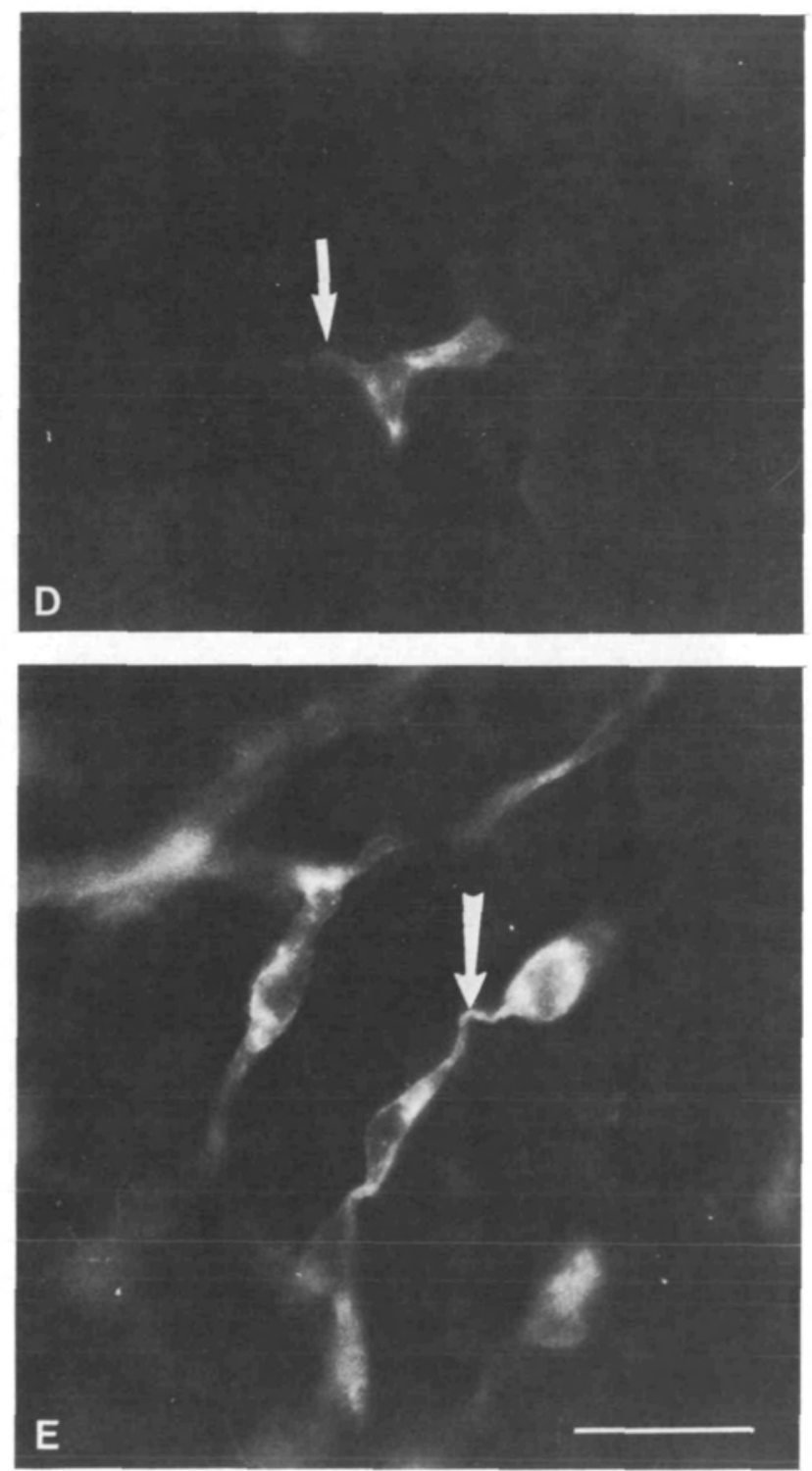

Fig. 3. Compared appearance of presumptive blood islands forming in the area opaca $(\mathrm{A}-\mathrm{C})$ and of the vascular network forming in the area pellucida $(\mathrm{D}, \mathrm{E})$ as seen by immunofluorescence using QH1 monoclonal antibody. Bar, $25 \mu \mathrm{m}$. (A) Two early blood islands joined by cellular protrusions (arrow). (B) Blood island with lumen forming (arrow) and cellular protrusion being extended (arrowhead). (C) A typical blood island with peripheral endothelium (arrowhead) surrounding positive cells within the lumen, presumably haemopoietic precursors (arrow). (D) Presumptive endothelial cells as they first appear in the area pellucida. Note the characteristic cytoplasmic extension (arrow).

(E) Single cells interconnecting via cytoplasmic extension (arrow) into an incipient network. 


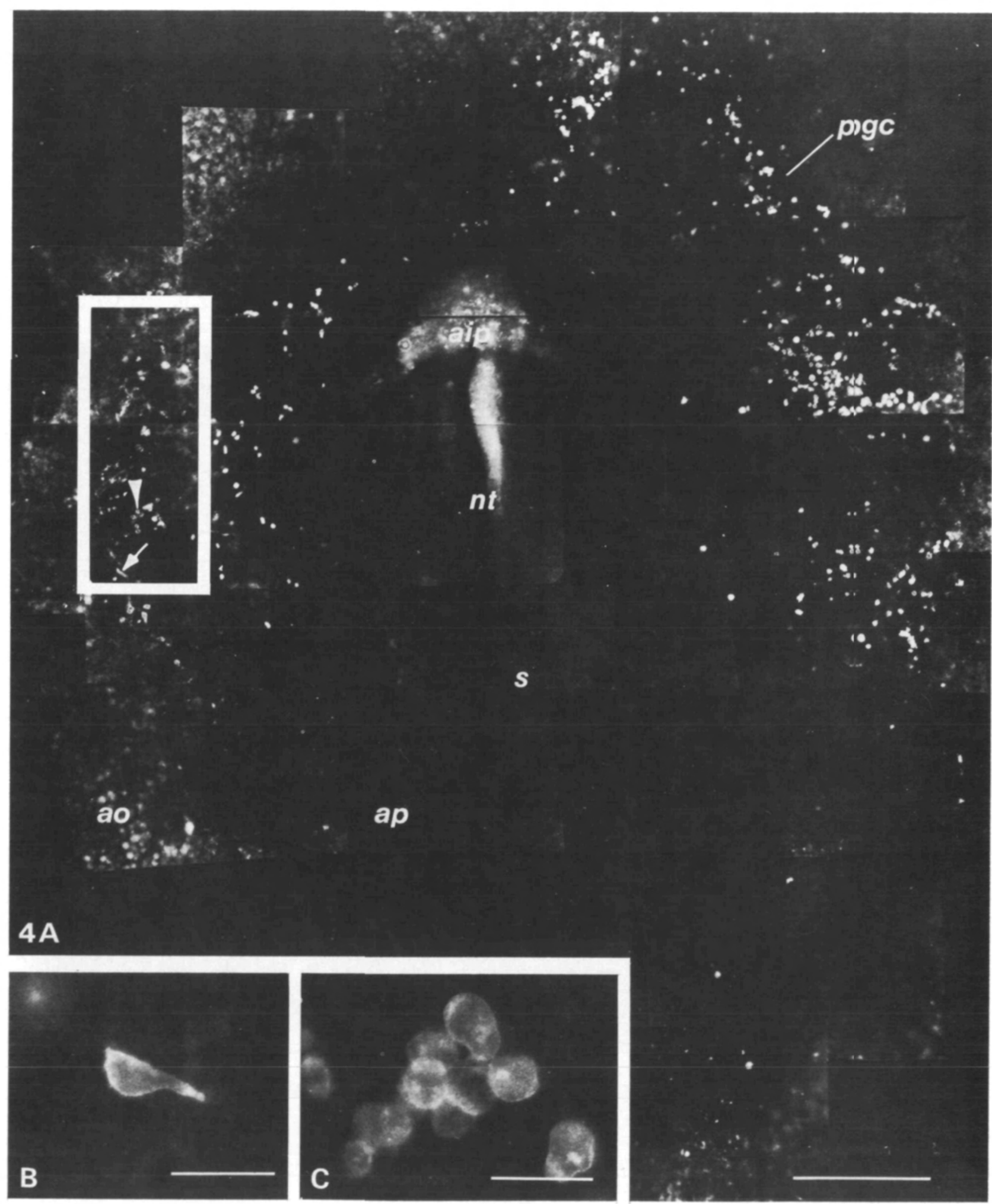

Fig. 4. (A) Wholemount of a 1-somite stage quail blastodisc reacted with QH1 (ventral view). Numerous single cells reacting with the antibody are distributed in the cephalic half of the blastodisc around the boundary between the area pellucida and the area opaca. Some endothelial cells interconnecting into a delicate network can be distinguished in the lateral area opaca. aip, anterior intestinal portal; $a o$, area opaca; $a p$, area pellucida; pgc (and line), primordial germ cells (PGC); $n t$, neural tube; $s$, location of the first somite, not visible in this photograph. Bar, $30 \mu \mathrm{m}$. In the framed area, endothelial cells have begun interconnecting (arrow), while PGC remain isolated (arrowhead). (B) Single spindleshaped endothelial cell in the area opaca as seen at head-process stage. Bar, $25 \mu \mathrm{m}$. (C) A group of round, nonconnecting PGC as they appear late (4-somite stage). These cells never interconnect. Bar, $25 \mu \mathrm{m}$. 
so that by the 5-somite stage (Fig. 5), the first signs of vascular organization are evident as numerous short thread-like processes which react with the QH1 monoclonal antibody. These are found in the anterior portions of the embryo extending from the somites to the head, both in the area pellucida and in the body of the embryo itself. There appears to be an early organization of the short thread-like network on the ventral side of the somites in the region to be occupied by the future dorsal aortas (arrows).

Vascular organization continues to progress rapidly so that in the early 7-somite embryo (Fig. 6), many of the small thread-like groups of cells can be seen to have connected into a more extensive network. There is a further concentration of the network ventral to the somites (arrows) as well as the condensation of the endothelial cells in the early heart with a 'feathering' of the heart endothelium into a network. There is also a marked increase in the presumptive vascular content of the heart and in the cephalic area of the embryo. The onset of formation of early head and brain vascularization is easily followed using this antibody. The extension of vascular endothelium continues to progress caudally just ahead of somite formation. No vasculogenesis has been initiated below the level of the sinus rhomboidalis.

Fig. 7 displays the whole extraembryonic and intraembryonic vascular tree in a more advanced 7-somite blastodisc stained with QH1. Though it has the same number of somites as that of Fig. 6, this blastodisc displays a more developed vascular tree. The heart is now seen to interconnect with the extraembryonic arborization. The aortas are more fully developed. Blood islands are present in the caudal region of the area opaca; in the photograph, their aspect is obscured by the presence of yolk platelets. The mesoderm-containing areas are sharply defined by the QH1-positive vascular network, with the exception of the sinus rhomboidalis and regressing streak region. In front of the embryonic forebrain, single primordial germ cells are visible in the region of the proamnion which is devoid of mesoderm. On more detailed examination, it can be seen that the sparse small thread-like network of endothelial cells has become more extensive and thickened. This is especially evident in the region of dorsal aorta formation. The network appears to be converging on the embryo in the region of heart development and somite formation. The rostral-caudal gradient of vascular development is particularly evident. In the rostral portion of the embryo, the network is more extensive and the individual presumptive vessels are much thicker than in the caudal portion. Here, the thin thread-like groups of cells seen in the 3- to 5-somite embryos are just forming. Also evident is the fact that the embryonic vascular network has anastomosed

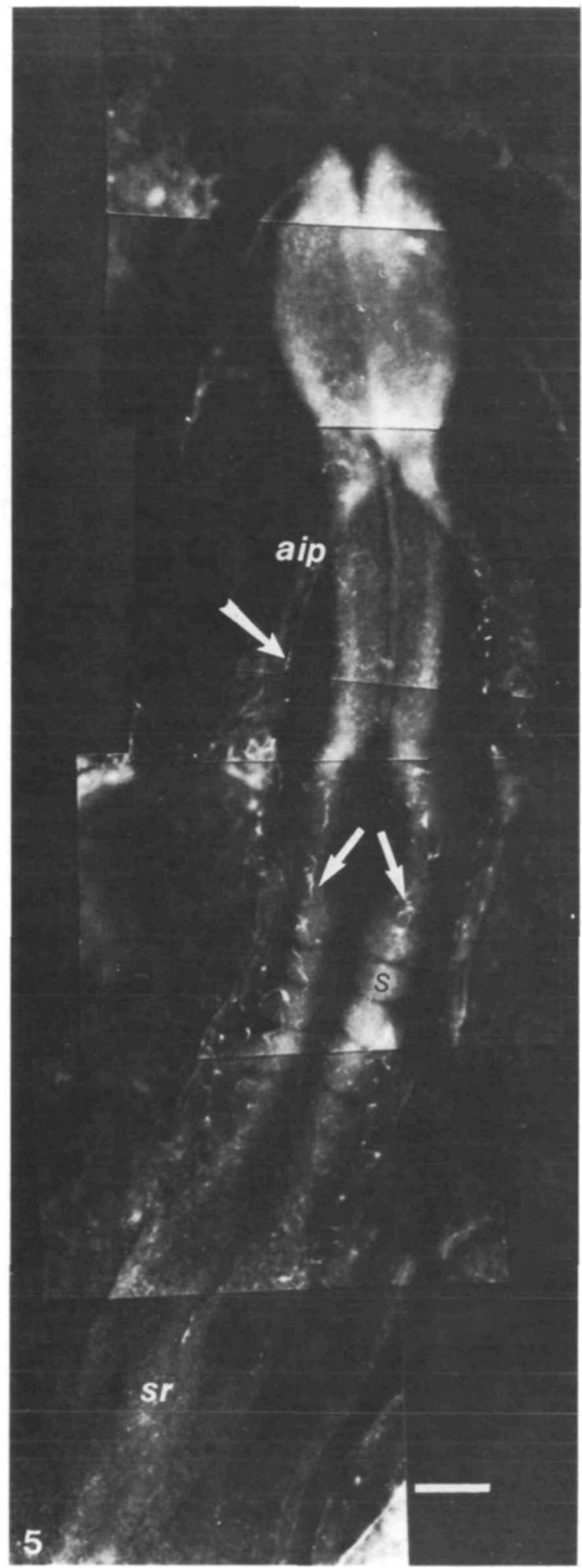

Fig. 5. Ventral view of a 5-somite blastodisc in the area pellucida reacted with QH1 monoclonal antibody. QH1positive endothelial cells interconnect into short, threadlike structures (arrows), notably in the anterior intestinal portal (aip) and along the ventral aspect of the somites $(s)$. Isolated positive cells are also present along the unsegmented somitic plate but none at the level of the sinus rhomboidalis (sr). Bar, $100 \mu \mathrm{m}$. 


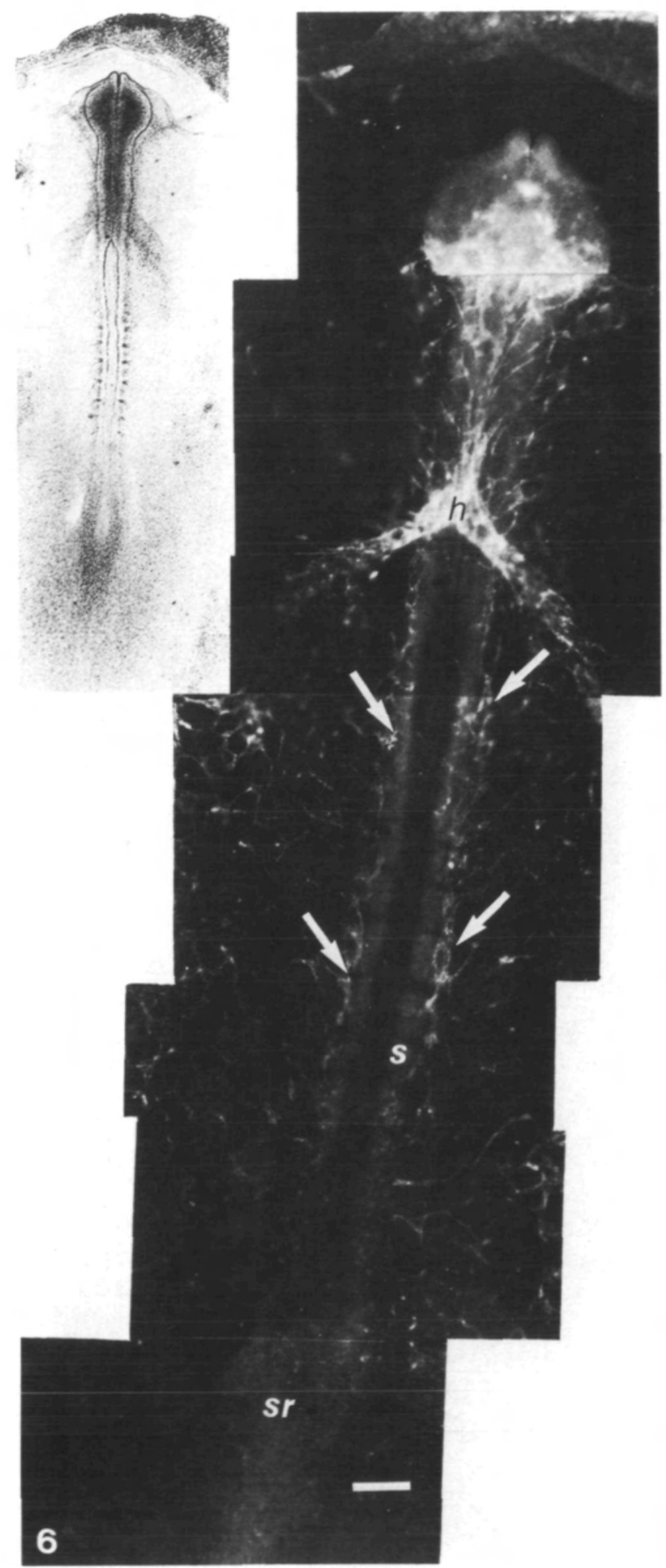

Fig. 6. Immunofluorescence of a ventral view of a 7-somite blastodisc exposed to QH1 monoclonal antibody. Phase contrast in the insert. The endothelial network is well developed within the area pellucida and, along the somites $(s)$, positive cells are forming the rudiments of the aortas (arrows). Within the anterior intestinal portal, the endothelial lining of the heart $(h)$ is laid down. $s r$, sinus rhomboidalis. Bar, $100 \mu \mathrm{m}$. with that of the developing yolk sac. Around the head of the embryo, single large fluorescing primordial germ cells are still visible. In contrast, is the absence of endothelial cells in the region of the proamnion (Insert, Fig. 7).

\section{Discussion}

Angiogenesis occurring through the budding of preexisting vessels has been studied in detail due in part to the fact that the budding endothelial cells are easily identified. In contrast, the formation of the initial vascular system in the developing embryo has been difficult to follow from its onset because of the absence of any means of identifying presumptive endothelial cells as they are formed. We have produced a series of monoclonal antibodies, following the injection of 12-day quail bone marrow cells into mice, which react with only a few cell types in the developing quail. These include endothelial cells, haemopoietic cells and cells tentatively identified as primordial germ cells on the basis of their well-known distribution in the developing blastodisc. These cell types could be distinguished from endothelial cells and hence presented no problem in the application of one of these monoclonal antibodies, QH1, to the study of the earliest events in vascular development.

Fig. 8 schematically summarizes vascular development as observed in whole quail blastodiscs using the QH1 monoclonal antibody. While the precise timing of events may vary somewhat from embryo to embryo, we were able to get a feeling for the dynamics of early vascular formation. The development of the embryonic vasculature commences in the anterior portion of the blastodisc between the levels of the first somite and the anterior intestinal portal and progresses rostrally in pace with the mesodermal germ layer and caudally at about the same rate as somitogenesis. Thus, in any one blastodic new presumptive endothelial cells are arising in the caudal portion of the embryo while the maturation of older vessels is occurring in the more anterior portions of the embryo. The formation of the extraembryonic vasculature begins earlier, but progresses caudally and rostrally in the same manner.

The first QH1-positive cells representing the anlage of the developing blood islands are seen at the headprocess stage in the area opaca. By the headfold stage, the individual blood islands are already beginning to interconnect. At this stage, a few cells can also be seen arising from the mesoderm in the area pellucida. These are the first presumptive endothelial cells. By the 3- to 5-somite stage, many of these cells are evident and they have begun to form thin threadlike networks. The regions of most intense embryonic vascular development are the headfold in the vicinity 


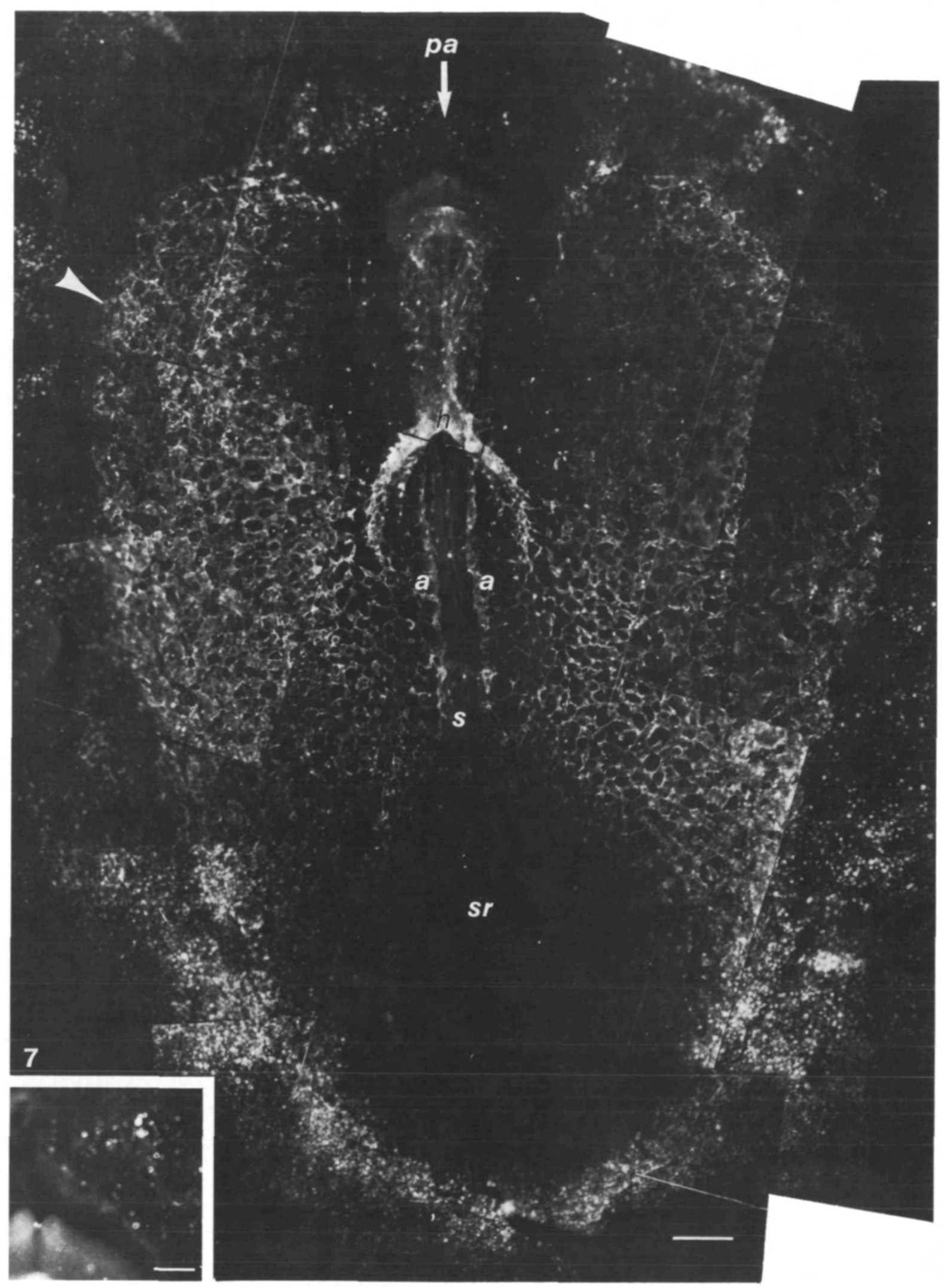

Fig. 7. Immunofluorescence of a ventral view of the entire surface of a 7-somite blastodisc exposed to QH1 monoclonal antibody. $a$, dorsal aortas; $h$, heart; $p a$, proamnion; arrowhead, outer edge of expanding blastodisc; $s$, somite; $s r$, sinus rhomboidalis. Bar, $200 \mu \mathrm{m}$. Insert: high magnification of the proamnion region showing nonconnecting PGC. Bar, $100 \mu \mathrm{m}$. 


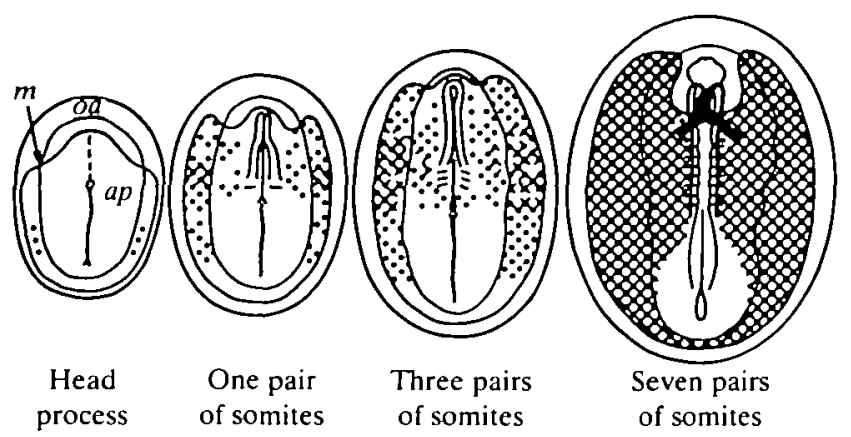

Fig. 8. Schematic representation of the ontogeny of the vascular network. It is clear that the emergence of positive cells (solid circles) and their interconnection into a vascular network in the area pellucida follows shortly that in the area opaca. Also depicted is the comparatively late acquisition of the 'horseshoe' shape (see Wilt, 1974) of the extraembryonic blood forming area. Finally, vascularization does not develop until later in the region of the regressing primitive streak. $a o$, area opaca; $a p$, area pellucida; $m$, limit of the mesoderm.

of the developing heart and the area pellucida in the region adjacent to the somites. By the 7 -somite stage, the vascular network has become more obvious and the presumptive vessels of the area pellucida are anastomosed with those of the area opaca. By the 5to 7-somite stage, endothelial cells have formed a bridge in the posterior region of the area opaca and the formation of the primary vascular tree is well underway. Thus, the formation of the initial vasculature from which all other vessels will arise occurs within a few hours.

Sabin (1920) following vasculogenesis in living blastodiscs explanted in vitro could identify endothelial cells beginning with the 4- to 5-somite stage. She noted also the rostral progression of vascularization and its parallel progression with somite formation. In addition, she was able to detect lumen formation which is not possible here given the use of whole, unsectioned blastodiscs. More recently, Hirakow \& Hiruma $(1981,1983)$ have studied vascular formation at the ultrastructural level. They were able to follow the details of canalization but could not observe the cells prior to their incorporation into recognizable structures. Similarly, Gonzalez-Crussi (1971) followed blood island formation at the ultrastructural level, monitoring both haemopoiesis and endothelium formation but again only after the process was initiated. Both these groups have commented on the necessity of a specific reagent, such as the monoclonal antibody $\mathrm{QH} 1$, for following the details of early vascularization.

Various model systems have been established to study angiogenesis (Schor \& Schor, 1983; Sariola, 1985). These systems all have in common the fact that the development of the vasculature, be it in transplanted tumours or embryonic rudiments (Saxen, Koskimies, Lahti, Miettinen, Rapola \& Wartiovaara, 1986; Folkman \& Handenschild, 1982; Sariola, 1985), involves a seemingly invasive process. That is, the transplanted tissue stimulates the budding of endothelial cells from pre-existing vessels. These cells penetrate the tissue fragment and establish the microvasculature required for the maintenance of the piece of tissue or tumour. These events may be fundamentally different from the process of formation of the primary vasculature shown here which clearly precedes later angiogenic processes and involves cells arising directly from the mesoderm. Detailed comparisons of these two processes are now possible using the antibody described here.

Attempts to characterize the antigen with which the QH1 monoclonal antibody reacts have been only partially successful. It clearly reacts with epitopes only expressed on quail embryos not on chick. The epitope is expressed on antigens found both within the cytoplasm and on the cell surface as the antibody will react with nonpermeabilized cells. The epitope is found on several different molecules, as immunoblots and immunoprecipitates reveal reactivity with molecules of varying molecular weights. In this sense, it resembles another antibody MB1 (Peault et al. 1983), which also reacts with quail endothelial cells and shows an affinity for several molecules ranging in $M_{\mathrm{r}}$ from 80 to $200 \times 10^{3}$, including quail IgM heavy chain and alpha 2 macroglobulin (Labastie, Poole, Peault \& LeDouarin, 1986). While the determination of the epitope (as opposed to any individual molecule) recognized by antibodies such as QH1 and MB1 is of obvious interest, the utility of the antibody at the present time rests in its use as a marker to follow specific developmental pathways. Using QH1 to identify presumptive endothelial cells, it is now possible to follow, for the first time, detailed primary vascularization of specific tissues, as well as design experiments to perturb vessel formation in order to gain some insight into factors (i.e. extracellular matrix, proteases, growth factors, other cell types, etc.) that may influence endothelial cell differentiation and vascular morphogenesis.

We acknowledge gratefully the efficient help of Bernard Henri and Yann Rantier with the photographic work, of Sophie Gournet for the drawing and of Lydie Obert and Marie Lennon for typing the manuscript. This work was supported by the Centre National de la Recherche Scientifique, by National Science Foundation grant INT 8413959 and by grants CA 19144 and CA 18015 to C. Buck from the National Cancer Institute. 


\section{References}

Buck, C. A., Dieterlen, F., Pardanaud, L., Kitos, P. \& AltmanN, C. (1985). Immunofluorescent studies of vascular development in early quail embryos. J. Cell Biol. 101, 112a.

Dieterlen-Lievre, F. \& Martin, C. (1981). Diffuse intraembryonic hemopoiesis in normal and chimeric avian development. Devl Biol. 88, 180-191.

Dieterlen-Lievre, F. (1984a). Blood in Chimeras. In Chimeras in Developmental Biology (ed. N. LeDouarin \& A. McLaren), pp. 133-163. London: Academic Press.

Dieterlen-Lievre, F. (1984b). Emergence of intraembryonic blood stem cells in avian chimeras by means of monoclonal antibodies. Devl Comp. Immunol. $3,75-80$.

Folkman, J. \& Haudenschild, C. (1982). Angiogenesis in vitro: Implications for tumor biology. In Pathology of the Endothelial Cell, pp. 79-93. New York: Academic Press.

Folkman, J. (1985). Tumor angiogenesis. Adv. Cancer Res. 43, 175-203.

Gonzalez-Crussi, F. (1971). Vasculogenesis in the chick embryo. An ultrastructural study. Am. J. Anat. 139, 441-460.

Hirakow, R. \& Hiruma, T. (1981). Scanning electron microscopic study on the development of the primitive blood vessels in chick embryos at the early somite stage. Anat. Embryol. 163, 299-306.

Hirakow, R. \& Hiruma, T. (1983). TEM-studies on development and canalization of the dorsal aorta in the chick embryo. Anat. Embryol. 166, 307-315.

Labastie, M. D., Poole, T., Peault, B. M. \& LeDouarin, N. M. (1986). MB1, a quail leukocyteendothelium antigen: Partial characterization of the cell surface and secreted forms in cultured endothelial cells. Proc. natn. Acad. Sci. U.S.A. 83, 9016-9020.
Murphy, M. E. \& Carlson, E. C. (1978). An ultrastructural study of the developing extracellular matrix in vitelline blood vessels of the early chick embryo. Am. J. Anat. 151, 345-376.

Peault, B., Thiery, J. P. \& LeDouarin, N. M. (1983). A surface marker for the hemopoietic and endothelial cell lineage in the quail species defined by a monoclonal antibody. Proc. natn. Acad. Sci. U.S.A. 80 , 2976-2980.

REAGAN, F. P. (1915). Vascularization phenomena in fragments of embryonic bodies completely isolated from yolk-sac blastoderm. Anat. Rec. 9, 329-341.

SABIN, F. (1920). Studies on the origin of the blood vessels and of red blood corpuscles as seen in the living blastoderm of chick during the second day of incubation. Contr. Embryol. 9, 215-262.

Sarjola, H., Peault, B., LeDouarin, N. M., Buck, C. A., Dieterlen, F. \& Saxén, L. (1984). Extracellular matrix and capillary in growth in interspecies chimeric kidneys. Cell. Diff. 15, 43-52.

Sariola, H. (1985). Interspecies chimeras: An experimental approach for studies on embryonic angiogenesis. Med. Biol. 63, 43-65.

Saxén, L., Koskimies, O., Lahti, A., Miettinen, L., Rapola, J. \& WartiovaARa, J. (1968). Differentiation of kidney mesenchyme in an experimental model system. Adv. Morph. 7, 252-293.

SchOR, A. M. \& Schor, S. L. (1983). Tumor angiogenesis. J. Pathology 141, 385-413.

Swift, C. H. (1914). Origin and early history of the primordial germ cells in the chick. Amer. J. Anat. 15, 483-516.

WAGNER, R. C. (1980). Endothelial cells embryology and growth. Adv. Microcirc. 9, 45-75.

WILT, F. H. (1974). The beginnings of erythropoiesis in the yolk sac of the chick embryo. Ann. N.Y. Acad. Sci. 241, 99-112.

(Accepted 17 February 1987) 